\title{
HOW DO POLICY DOCUMENTS RELEVANT TO REFUGEES ADDRESS ISSUES RELATING TO REFUGEE'S ACCESS TO HEALTH CARE SERVICES IN SOUTH AFRICA?
}

\author{
Ganzamungu Zihindula ${ }^{1}$, Olagoke Akintola $^{2}$, \& Anna Meyer-Weitz ${ }^{3}$ \\ 1,2,3 Discipline of Psychology, School of Applied Human Sciences, \\ University of KwaZulu-Natal, Durban-RSA \\ ${ }^{1}$ Africa Health Research Institute (AHRI), Somkhele site, Nothern KwaZulu-Natal, South Africa \\ ${ }^{2}$ School of Human and Social Development, Nipissing University, \\ North Bay, Canada \\ gzihindula@gmail.com
}

\begin{abstract}
Background: There is very limited literature on the provisions contained in policies relevant to refugees who seek health care services in South Africa. Yet, the need to understand how policy can influence access to healthcare services for refugees is widely acknowledged.

Purpose: This study was conducted in order to examine ways in which policy documents relevant to refugees address issues relating to refugees' access to health care services.

Methods: Data for this study was derived from a review of policy documents relevant to refugees and discussions with relevant stakeholders. Six provisions were identified that relate to the facilitation of health care access among refugees. Twelve $(n=12)$ relevant policy documents that met our inclusion criteria were analysed in terms of the six provisions and particularly how it was framed.

Findings: The six provisions pertain to refugees' rights and access to healthcare services, free access to ART, access to mental health, screening upon arrival and provision of interpreters at public healthcare facilities. The findings suggest that policy documents have not adequately addressed issues relating to refugees' access to health care services in South Africa. Of the 12 relevant policy documents selected, only seven had one or two of the six provisions; the other five made no provision for refugees in South Africa. In addition, most of the policy documents that address the issue of health care access for refugees are international documents. Only four policy documents developed in South Africa contained one or two of the six provisions.

Conclusion: Health policy makers should pay attention to the issues of refugee health within government's limited financial and human resource capacity as it has important health ramifications for the citizens and the country at large. Further, government and policy makers should also promote access to resources to support health facility management and create greater awareness of national health policies among practitioners and refugees.
\end{abstract}

Key words: Health policy, Refugees, Access to healthcare, South Africa

\section{Introduction}

In January 2015, the United Nations High Commission for Refugees (UNHCR) documented 59.5 million forcibly displaced people worldwide (UNHCR, 20I5). This number includes both refugees and asylum seekers. South Africa is a preferred destination for forced migrants from other African countries and is currently home to 315000 refugees and asylum seekers, making the country a leading host to asylum seekers on the African continent (Amnesty International, 20I5; Human Right Watch, 2015; Zihindula, Meyer-Weitz \& Akintola 2015). Defined by the United Nations as persons that have http://aps.journals.ac.za been forced out of their countries of origin (UNHCR 1945), refugees come from challenging backgrounds resulting from war, political instability, torture and other forms of violence and diverse challenges (Annan 20l4; Bachishoga \& Johnston 2013; Maniragena 2014; Sirin \& Rogers-Sirin 2015; Warfa, Curtis, Watters, Carswell, Ingleby \& Nhui 20I2).

Upon their arrival in the host countries, refugees confront further challenges that affect their psychological, health, social and economic wellbeing. International organizations and specifically the UNHCR have developed policies to address these 
challenges (Gray \& Vawda 20I4). South Africa is a signatory to many policies that advocate for access to health care services by refugees (Greenburg \& Polzer, 2008; Republic of South Africa, 1998). In addition, the government of South Africa has since 1994 placed equity at the core of its health policies (Gilson \& Mclntyre 2007). The main objective of all health policies in South Africa was to address the legacy of apartheid and to reduce the enormous inequities in access to health care services and health status (Benatar, 20 I3; Harris, Goudge, Ataguba et al. 201I; Nevondwe \& Odeku 2013). The Refugee Act of 1998 and the National Health Care Act of South Africa of 2003 stipulate that everyone who lives in South Africa has the right to access health care services (HRW, 20I5; Republic of South Africa, 1998). These provisions in both Acts are not reflective of the situation on the ground as studies have shown that refugees lack access to health care services in South Africa, despite the existence of both the National Health Care Acts and the South African constitution (Apalata et al. 2007; Crush \& Tawodzera 2014; Maniragena 20I4; Zihindula et al. 20I5). Regrettably, there is a dearth of studies about how policy documents address issues related to refugees' access to healthcare services in South Africa. Therefore, the purpose of this study was to examine the ways in which relevant health related policy documents address the issue of access to health care services by refugees.

Literature review
The current literature on policy and implementation outcomes regarding health care service access by refugees is sparse, particularly within the South African context. Yet, the need to understand how policy and implementation can influence access to healthcare services for refugees is widely acknowledged. Access to health care services has been defined in different ways by diverse authors and researchers. The IOM (1993:04) defined access to health care services as having a timely use of personal health services to achieve the best health outcomes. Levesque, Harris \& Russell (20/3:3) define access to health care as an individual's ability to identify his/her need and seek healthcare services and obtain the relevant care for his/her healthcare needs. For the purpose of this study, access to health care was defined as the opportunity to reach and obtain appropriate health care services in situations of perceived need for care (Goddard \& Smith 200I; Haddad \& Mohindra 2002; Olivier \& Mossialos 2004; Waters 2000). These definitions refer to the ability of service providers to deliver health care services to all in need of health services in a way that is affordable and acceptable. They should also provide equal access and utilization of the services by every individual in need of health care services.

Issues relating to policy about access to health care services for refugees in South Africa are crucial as the number of refugees and asylum seekers continues to grow in South Africa (See Table I).

Table I

\begin{tabular}{|c|c|c|c|c|c|c|c|}
\hline \multicolumn{8}{|c|}{ United Nations Higher Commission for Refugees (UNHCR): Planning Figures for South Africa } \\
\hline \multirow{2}{*}{$\begin{array}{l}\text { TYPE OF } \\
\text { POPULATION }\end{array}$} & \multirow[t]{2}{*}{ ORIGIN } & \multicolumn{2}{|c|}{ December 2013} & \multicolumn{2}{|c|}{ December 2014} & \multicolumn{2}{|c|}{ December 2015} \\
\hline & & $\begin{array}{l}\text { Total in } \\
\text { Country }\end{array}$ & $\begin{array}{l}\text { Of } \\
\text { whom } \\
\text { assisted } \\
\text { by } \\
\text { UNHCR }\end{array}$ & $\begin{array}{l}\text { Total in } \\
\text { Country }\end{array}$ & $\begin{array}{l}\text { Of } \\
\text { whom } \\
\text { Assisted } \\
\text { by } \\
\text { UNHCR }\end{array}$ & $\begin{array}{l}\text { Total in } \\
\text { Country }\end{array}$ & $\begin{array}{l}\text { Of whom } \\
\text { assisted by } \\
\text { UNHCR }\end{array}$ \\
\hline Refugees & Various & 67,500 & 13,500 & 75,600 & 15,120 & 83,600 & 16,720 \\
\hline Asylum-Seekers & Various & 233,100 & 46,620 & 274,400 & 54,880 & 283,700 & 56,740 \\
\hline Total & & 300,600 & 60,120 & 350,000 & 70,000 & 367,300 & 73,460 \\
\hline
\end{tabular}

Source: 20I4's UNHCR planning figures for South Africa

In 20II, the South African government published a green paper on the National Health Insurance (NHI) which was intended to ensure equal access to appropriate, efficient and quality health services for everyone (Naidoo, 20I2). The $\mathrm{NHI}$ policy intends to address the quadruple burden of diseases including HIV/AIDS \& TB, maternal and childhood diseases, non-communicable diseases as well as violence and injury), which are responsible of over $90 \%$ of deaths in South Africa (Dudley, Selebano, Nathan et al., 2013; Matsoso 2013; Mash, Malan, von Pressentin \& Blitz, 2015; Matsoso, Fryatt \& Andrews 2015). Unfortunately, the $\mathrm{NHI}$ policy makes very little reference to issues relating to refugees' access to healthcare services.

It has been documented globally that refugees face a myriad of challenges in attempting to access health care services despite the existence and 
implementation of policy developed to facilitate access and utilisation of healthcare services for refugees (HRW, 2009; Langlois et al 2016; Milosevic 2012; UNHCR 20II; UNHCR 2013). These challenges include language barriers, documentation, cultural and health seeking behaviours of refugees, health care workers' attitudes and the issues of affordability where user fees are charged for health care services (Asgary \& Segar 20Il; Aspinall \& Watters 2010). Similar results as the above were documented in a study about refugees' access to health care services in European Union countries (Langlois, Haines, Thomson \& Ghaffar 2016). The findings of the study by Langlois et al suggest that despite the health policy implementation at facility level, refugees were still confronted with challenges of communication, acceptability and affordability of health care services. This finding is consistent with that of Szajina \& Ward (20I5) who studied refugees' access to health care services in the United States of America and found that culture, language discrimination, stigmatization and logistical concerns were the dimensional barriers to refugees accessing healthcare services.

Studies conducted in South Africa show that national health systems often discriminate against refugees (CoRMSA 2009; HRW 20I5; Moyo 2010; MSF 20I0; IOM 2009; Vearey 20I4; Zihindula et al. 2015). A report from the Jesuit Refugee Services (JRS) in Johannesburg indicated that refugees find it challenging to access health care services in South Africa because the health facilities do not provide interpreters to assist the refugees who are not able to communicate in a local language. This finding is supported by a number of other studies conducted among refugees living in South Africa (Apalata et al. 2007; Magqibelo et al. 2016; Zihindula et al. 2015) Additionally, studies have shown that health care workers deny services to refugees on the basis of their immigration status (Crush and Tawodzera 2014; JRS 20I4; SAMP 20I5; Vearey 20I4). Studies that explored refugee access to health care services in South Africa revealed that refugees confront medical xenophobia when trying to access health care services (Nkosi 20l4; Crush \& Tawodzera, 20l4). However, we know very little about how health policy documents address issues relating to refugee's access to health care services in South Africa.

\section{Methods}

This study is part of the first author's doctoral thesis that explored refugees' access to health care services in South Africa.

\section{Policy document collection and selection strategy}

We developed a process to help in collecting policy documents available in the public domain that we deemed potentially relevant to the purpose of our study. We chose to collect policy documents that were I) developed or published from 1994 when democratic rule began in South Africa and 2) reviewed and recommended for inclusion by stakeholders. We took the following steps in order to search for and collect relevant documents:

I. Reviewed international Acts and policies relevant to refugees and policy documents of the United Nations High Commission for Refugees (UNHCR) that are relevant to South Africa.

2. Reviewed South African National Strategic Plans (NSPs), Provincial Strategic Plans and South African National Department of Health policies and frameworks relevant to refugees and health care access.

3. Reviewed the South African Refugee Act.

4. Vsited organizations assisting refugees in South Africa to discuss issues relating to health policies and refugee policies (see Table 2). The discussion allowed us to determine which documents, policies and organisations should be included in the study and to verify and ensure that all the major health policies are covered in this study.

5. We used the websites of refugee centers that we could not access to retrieve information related to their policy on refugee's access to health care services in South Africa.

6. We consulted with the directors of the Department of Home Affairs in the city of Durban, KwaZulu-Natal province, Pretoria, Gauteng province and Musina in Limpopo province, to explore if they had further relevant policy documents relating to refugees. We also had an informal conversation with them regarding ways in which they assist refugees who seek access to health care service.

7. To verify further that we have exhausted information about refugees, we considered reviewing literature that documents issues relating to migrants. The Southern African Migration Project (SAMP), the Centre for Migration and Society (ACMS), and the Consortium for Refugees and Migration in South Africa (CorMSA) are the institutions' websites that we visited and we got specific information crucial to this work (ACMS 20I5; SAMP 20I5).

Through all these processes we collected a total of 39 policy documents that we believed were relevant to the purpose of our study. We set the following inclusion criteria to assist in the selection of documents: I) policy documents should be relevant to and adopted by South Africa 2) relevant to refugees and 3) have some relevance to health care provision or access. Only 12 policy documents 
remained after we applied our explicit inclusion criteria (see Figure I).

Figure 1:

Reviewed relevant policies and documents from internet sources:

Collected 19 documents from Google scholar, EBSCOHost, SA Department of Health, UNHCR, SAG and all refugees service centres in South Africa

\section{Governmental departments visited:}

Visited national and provincial DOH for meetings and collection of nine (9) policy documents
Refugee affairs institutions visited:

Visited four (4) Departments of Home Affairs five (5) Refugee Social Services Centres and two (2) Lawyers for Human Rights Offices

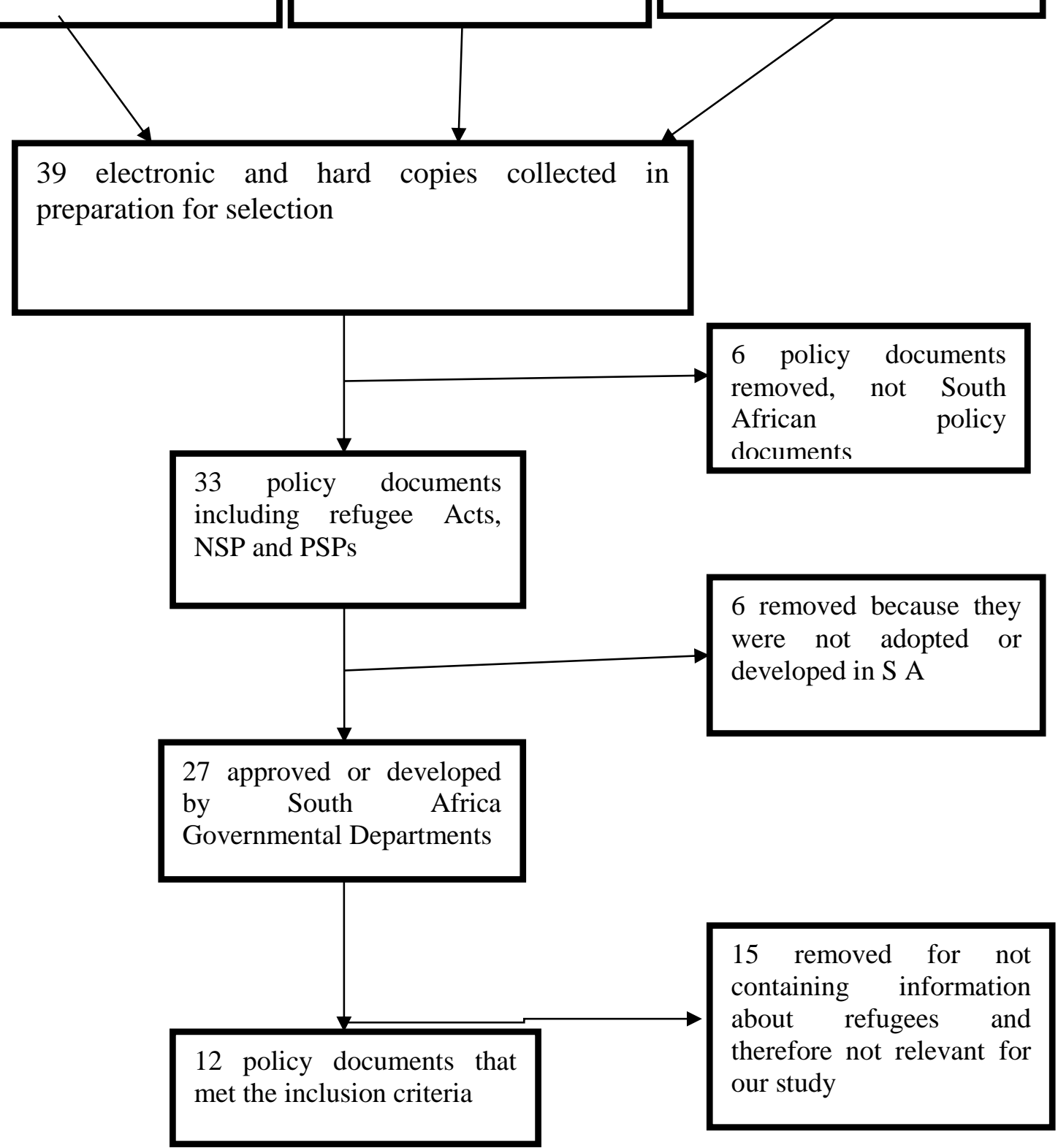

Figure I: Flow chart showing the process of collecting and selecting documents 
African Population Studies Vol 3I, No I, 2017

Table 2: Institutions assisting refugees in South Africa and services provided

\begin{tabular}{|c|c|c|}
\hline Organization Names & Location & Refugee-related activities/ Focus area \\
\hline $\begin{array}{l}\text { Department of Home } \\
\text { Affairs (DHA) }\end{array}$ & $\begin{array}{l}\text { In } 3 \text { provinces } \\
\text { in South } \\
\text { Africa }\end{array}$ & $\begin{array}{l}\text { This department is a South African Governmental } \\
\text { department working with refugees and asylum } \\
\text { seekers providing them with status documents } \\
\text { and permits respectively, in order for them to stay } \\
\text { legally in the country. }\end{array}$ \\
\hline $\begin{array}{l}\text { South African Refugee } \\
\text { Action (SARA) }\end{array}$ & Johannesburg & $\begin{array}{l}\text { Provides paralegal assistance and support to } \\
\text { newly arrived asylum seekers. }\end{array}$ \\
\hline $\begin{array}{l}\text { Consortium for Refugees } \\
\text { and Migration in South } \\
\text { Africa (CorMSA) }\end{array}$ & Johannesburg & $\begin{array}{l}\text { Promotion and protection of rights of asylum } \\
\text { seekers, refugees and international migrants. }\end{array}$ \\
\hline $\begin{array}{l}\text { Jesuit Refugee Services } \\
\text { (JRS) }\end{array}$ & Johannesburg & $\begin{array}{l}\text { A faith-based organization (FBO) which provides } \\
\text { social assistance to refugees and Asylum seekers } \\
\text { in the Republic of South Africa. }\end{array}$ \\
\hline El-Shaddai Hands of Mercy & Musina & $\begin{array}{l}\text { A faith-based organization which provides } \\
\text { spiritual and psychosocial support services to } \\
\text { refugees, and feeds only refugees and asylum } \\
\text { seekers with valid section } 22 / 23 \text { permits. }\end{array}$ \\
\hline $\begin{array}{l}\text { Cape Town Refugee Centre } \\
\text { (CTRC) }\end{array}$ & Cape Town & $\begin{array}{l}\text { Psychosocial intervention programmes including- } \\
\text { emergency services, medical assistance (referral } \\
\text { to hospitals), funerals, education, programmes for } \\
\text { children, empowerment and self-reliance } \\
\text { programmes, income generating livelihood } \\
\text { grants, translation and evaluation of foreign } \\
\text { qualifications. }\end{array}$ \\
\hline $\begin{array}{l}\text { Sonke Gender Justice } \\
\text { Network-HIV/AIDS, } \\
\text { Gender Equality, Human } \\
\text { Rights }\end{array}$ & $\begin{array}{l}\text { Cape Town, } \\
\text { Johannesburg } \\
\text { and } \\
\text { Mpumalanga }\end{array}$ & $\begin{array}{l}\text { The organization works across Africa and it aims } \\
\text { to facilitate equal access to health, pursues human } \\
\text { rights framework to build civil societies and } \\
\text { governments' capacity and citizens to prevent } \\
\text { gender-based violence and reduce the spread of } \\
\text { HIV }\end{array}$ \\
\hline $\begin{array}{l}\text { Agency or Refugee } \\
\text { Education, Skills Training } \\
\text { and Advocacy (ARESTA) }\end{array}$ & Cape Town & $\begin{array}{l}\text { The organisation assists asylum seekers and } \\
\text { refugees with education, legal matters and } \\
\text { integration into South Africa upon their arrival in } \\
\text { the city of Cape Town }\end{array}$ \\
\hline $\begin{array}{l}\text { People Against Suffering } \\
\text { Oppression and Poverty } \\
\text { (PASSOP) }\end{array}$ & Cape Town & $\begin{array}{l}\text { The organisation raises awareness of } \\
\text { discrimination against LGBTI, asylum seekers } \\
\text { and refugees in South African employment and } \\
\text { housing market. It also raises awareness about the } \\
\text { asylum process in the country. }\end{array}$ \\
\hline
\end{tabular}

\section{Analysis of policy documents}

The analysis followed a step-by step process which began with a review of relevant literature and policy documents globally as well as discussions with relevant stakeholders to derive provisions that could facilitate access to health care among refugees. A total of six provisions were derived: provision for refugee services in general, refugees' right to access health care services, health screening of refugees upon arrival in South Africa, free access to antiretroviral services, refugee access to mental health services and the provision of translators at public health facilities. These provisions were discussed with relevant stakeholders before we proceeded to assess the policy documents for the presence or absence of the provisions (see Figure 3). 
Figure 3: Analysis process

Derived 6 provisions from a review of refugee health policies in Canada, Australia/ New Zealand and USA as well as studies conducted among refugees in SA
Six provisions revised and approved during meetings with policy makersand organizations providing social services to refugees

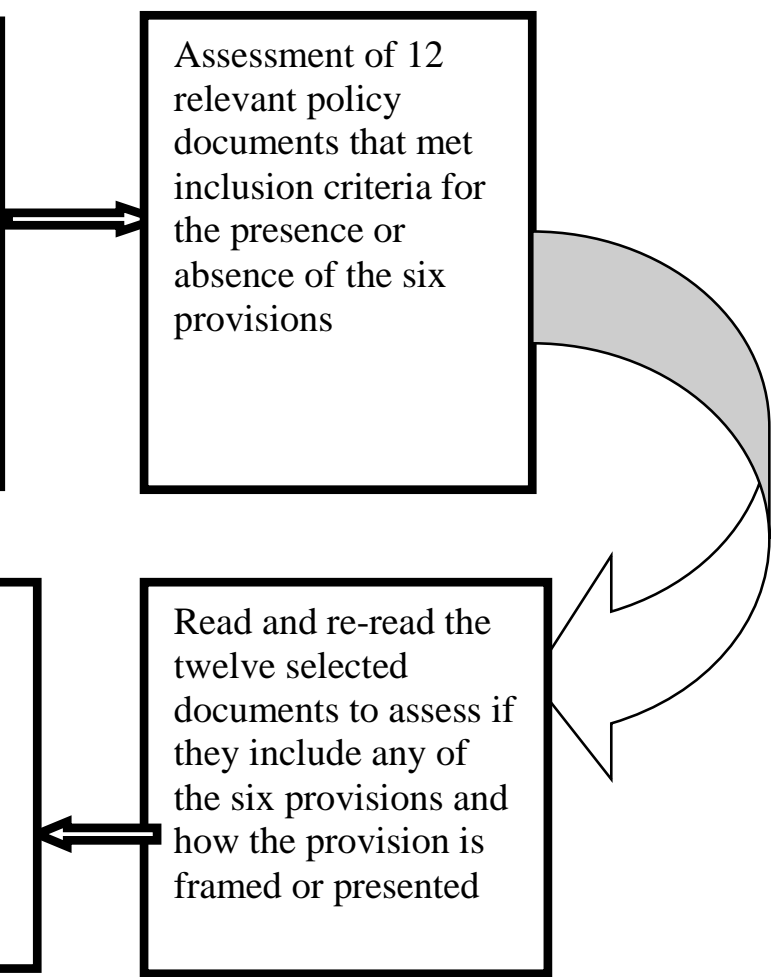

Reading \& ticking policy analysis and preparation of discussion.
Development of a table for recording the presence or absence of any of the 6 provisions

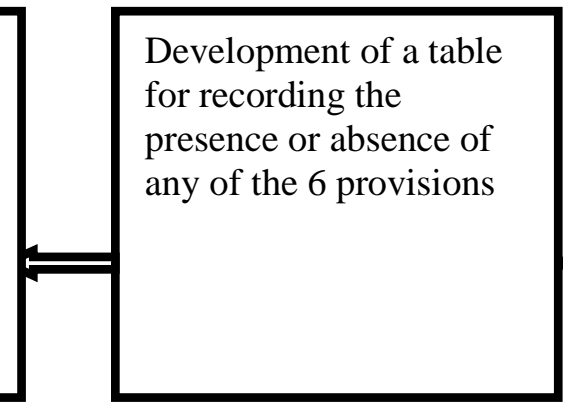

Read and re-read the twelve selected documents to assess if they include any of the six provisions and how the provision is framed or presented

Source: Authors

\section{Results}

Table 3 shows a comprehensive review of all Acts, policies and strategic plans analysed in this study.

Table 3: Provisions of the policies relevant to access to health care services

\begin{tabular}{|c|c|c|c|c|c|c|}
\hline & $\begin{array}{l}\text { Provision } \\
\text { for } \\
\text { Refugees } \\
\text { services }\end{array}$ & $\begin{array}{l}\text { Refugee's } \\
\text { right to } \\
\text { access } \\
\text { healthcare }\end{array}$ & $\begin{array}{l}\text { Health } \\
\text { screening } \\
\text { upon } \\
\text { arrival }\end{array}$ & $\begin{array}{l}\text { Free } \\
\text { access } \\
\text { to } \\
\text { ARVs }\end{array}$ & $\begin{array}{l}\text { Access to } \\
\text { mental } \\
\text { health } \\
\text { services }\end{array}$ & $\begin{array}{l}\text { Translators } \\
\text { at health } \\
\text { facilities }\end{array}$ \\
\hline ANC Health Policy 1994 & & & & & & \\
\hline $\begin{array}{l}\text { South African constitution Act, } \\
108 \text { of } 1996\end{array}$ & $\sqrt{ }$ & & & & & \\
\hline $\begin{array}{l}\text { International Refugee Act } \\
1998\end{array}$ & $\sqrt{ }$ & $\sqrt{ }$ & & $\sqrt{ }$ & $\sqrt{ }$ & \\
\hline National health Act 61 of 2003 & & $\sqrt{ }$ & & & & \\
\hline $\begin{array}{l}\text { UN Declaration of Human } \\
\text { Rights } 2006\end{array}$ & $\sqrt{ }$ & $\sqrt{ }$ & $\sqrt{ }$ & $\sqrt{ }$ & & \\
\hline UNHCR policy 2009 & $\sqrt{ }$ & $\sqrt{ }$ & $\sqrt{ }$ & $\sqrt{ }$ & $\sqrt{ }$ & \\
\hline $\begin{array}{l}\text { National Health Insurance } \\
\text { (NHI) } 2011\end{array}$ & $\sqrt{ }$ & & & & & \\
\hline
\end{tabular}


African Population Studies Vol 3I, No I, 2017

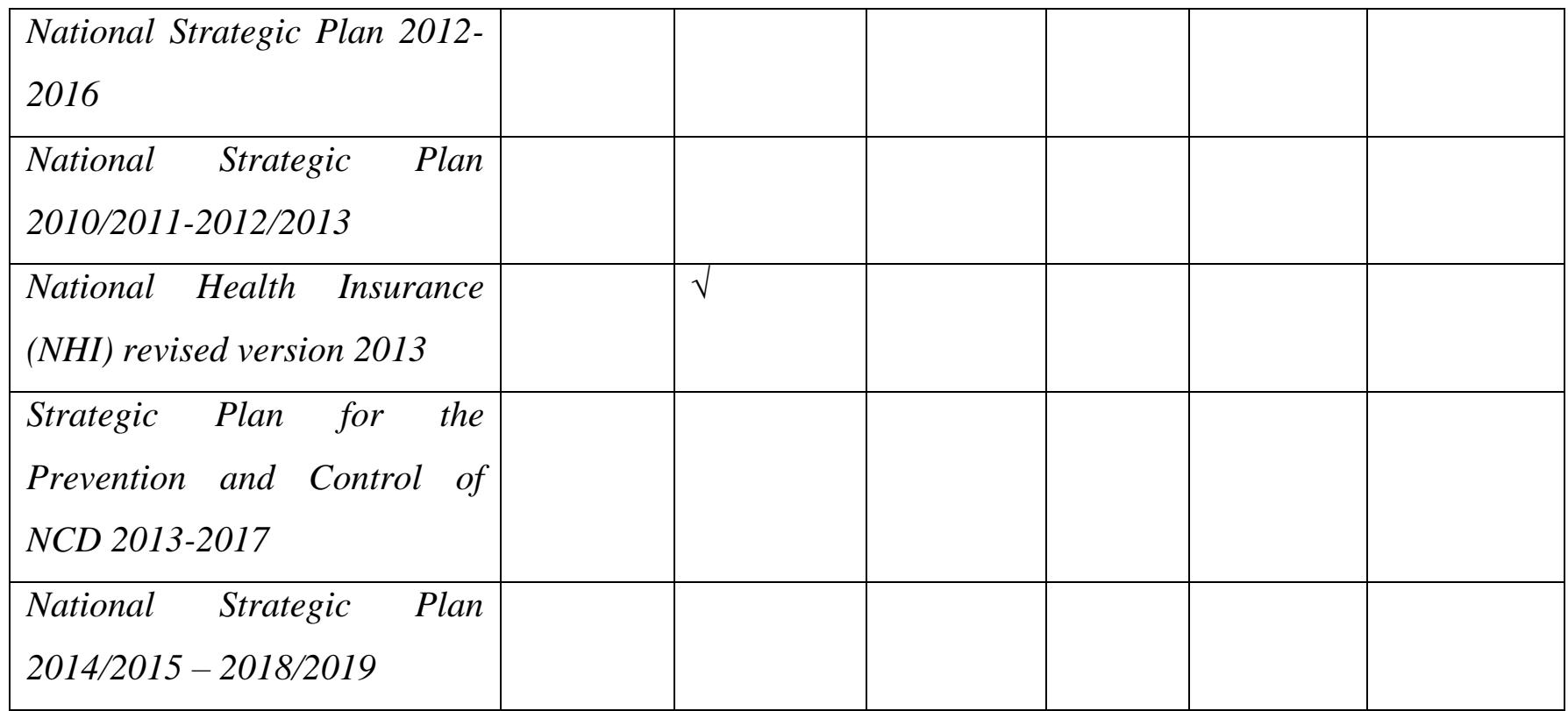

This study provides insight into provisions that are contained in policy documents that could influence refugees' access to health care. Some of the policy documents make provisions for refugees' access to health care services, screening upon their arrival, HIV/AIDS and TB tests, access to sexual and reproductive health $(\mathrm{SRH})$ services and equal treatment similar to South African citizens.

Five policy documents out of twelve advocated for equal access to general services for refugees in South Africa. The services are social, economic, education and other services necessary for a good quality of life. The key to refugee access to health care services is to have relevant policies adopted and implemented by the South African government. The majority of the relevant policy documents we reviewed did not include the provision for refugees' rights to access health care services. Less than half of the policy documents advocated for refugee rights to access health care services and this is a barrier to refugees' access to health care services as policy is understood to be a document of reference for service delivery.

As shown in Table (3), only three of the 12 policy documents highlighted that refugees should have free access to ART in South Africa, while other policy documents were silent about this issue. The three policy documents were developed internationally i.e. the United Nations, the International Refugee Act and the UNHCR respectively but have been adopted by South Africa. They all advocate for refugees' rights to access ART in South Africa.

Only two i.e. The International Refugee Act 1998 and the UNHCR policy 2009 - of the 12 documents analysed contained a provision for refugees with mental illness. The UNHCR 2009 policy stipulates that refugees should be screened for mental health related illnesses upon arrival. Further, the policy http://aps.journals.ac.za stipulates that refugees should be screened for mental health problems when they present at any public health facility. But both were international documents. None of the policy documents developed in South Africa had any provision for mental health services to refugees.

\section{Discussion}

The selection of these six provisions was based on the literature documenting the dominant health needs of refugees in host countries and the factors identified as influencing refugees' access to health care services by organisations that support refugees (ACMS 2015; Duncan 2015; Gray \& Vawda 2014; Langlois et al 2016; Manirangena 20I4; SAMP 2015; Vearey 20I5; Weissbecker \& Leichner 2015). Hence this report includes only relevant policies that have potential or that include a clause that advocates for refugee access to health care services in South Africa.

Furthermore, the Refugee Act of 1998 does not make explicit refugees' rights to access health care services in South Africa. The Act only stipulates that refugees shall benefit from services provided by the government equally as their local counterparts. The Act provides no details or limitation to the services, yet the literature has shown that refugees have been denied rights to access many socio-economic services including health care services (Apalata et al. 2007; Crush \& Tawodzera 2014; Vearey 2014; Zihindula et al. 20I5).

\section{Provision for refugee services}

Despite their official adoption, the policies that we reviewed made limited provisions for refugees to access health care services in South Africa. Out of the 12 policy documents reviewed, only five have been implemented and are operational. These five are all addressing refugee access to health care 
services, social, political and educational services in general. The five relevant policies suggest that refugees should have free access to every service provided by the government to South African citizens. The services cited include free education at public schools, benefit from social grants and any other social services, a right to a high standard of life like all other citizens and access to free healthcare services. The question remains however whether some of these provisions are adopted and adhered to by service providers. Researchers have argued that there are many policies adopted or developed by the health sector which if implemented and operational could address the unequal access to healthcare services in South Africa (Grey \& Vawda 2014; Rispel \& Morman 2010; Zihindula et al. 2015).

\section{Screening of refugees upon arrival}

The United Nations High Commission for Refugees (UNHCR) recommends that all actors involved in the protection and assistance of refugees should provide them with humanitarian response in ways that are beneficial to their psychological wellbeing and mental health (UNHCR 20I5). We found only a few studies relating to the screening of refugees after their arrival in the host countries. Shannon et al. (20ll) conducted a survey of refugee health coordinators in 44 States of the USA to assess health screening practices and barriers to screening. The results suggested that only 25 states provided screening to refugees and of these, 17 utilised informal conversations instead of standardized measures (i.e. screening refugees for HIV/AIDS \& TB, high blood pressure malaria, sugar diabetes and other communicable and non-communicable diseases instead of asking verbal questions which are likely to provide wrong diagnoses). The main challenges identified by this study were that the management of the health facilities were not prepared for the screening, other facilities lacked resources (human) while others did not have standardized measures in place to screen refugees upon arrival (Shannon et al 20II).

However, some countries have made progress towards screening of refugees for different diseases upon their arrival. This policy has been successfully implemented in countries like New Zealand, Greece, Scandinavian countries, Australia, Canada and some USA states (Duncan 2015; McKerry \& NewBold 2010; UNHCR 2015). Unfortunately, out of the 12 policy documents analysed, only two, both international, recommended the screening of refuges upon arrival. The UN Declaration of Human Rights 2006 and the UNHCR Policy of 2009 advocated for refugee screening upon arrival. None of the national policies made any provisions for refugee screening 3241 upon arrival in South Africa. Refugees who are not screened pose a potential health risk to the host community and this has cost implications for the health system as refugees will only discover their health conditions and start seeking health care services when they become severely ill (Morris et al 2009; Zihindula et al. 2015). There are however some barriers to screening of refugees. For example, in the South African context, the country has a severe shortage of health care practitioners and drug supply (South African Academy of Family Physicians 20I4). Furthermore, cultural insensitivities of HCPs and health seeking behaviours of the refugees make it difficult to screen refugees upon arrival (Department of Higher Education and Training [DHET] 2014; Zihindula et al. 20I5).

\section{Policies regarding refugees and rights to access health care services}

Literature on refugee related policies and access to health care services is very sparse (Griffiths 2015; Pillay \& Thulare 20II). However, our analysis suggests that only a few policy documents included a provision for refugees to access any form of health care services. Of the 12 relevant policy documents, only five included a provision for refugees' rights to access healthcare services.

Moreover, most of the policy documents analysed in this study contained information that was somewhat contradictory and/or not implemented. For instance, the NHI policy document published in 201 I stresses that refugees and asylum seekers will be covered in line with the provision of the Refugee Act of 1998 and the International Human Rights' instruments that have been ratified by the South African government (DOH 2008). This statement is somewhat ambiguous. Interestingly, the revised version of $\mathrm{NHI}$ released in 2013 neither made reference to the Refugee Act nor provisions for refugees. Instead it states that every citizen of South Africa will benefit from the policy. It is important to note that some stakeholders have criticized the $\mathrm{NHI}$ document for not adequately addressing the problems of marginalized populations (CMS 20I2). The Council for Medical Scheme (CMS) argue that the NHI policy will not be successful unless it adequately addresses the socio-economic inequalities in the country and implement the 10 point plan $(\mathrm{DOH} 2014)$. The ten point plan is a programme developed by the government to guide the country in strengthening the health systems and its management as well as service delivery in the public health sector (CMS 2012; DOH 20/4)). This suggests that the provisions in the $\mathrm{NHI}$ may not adequately address issues relating to access to health care among other disadvantaged populations in South Africa such as the http://aps.journals.ac.za 
poor people. This calls for synergy and collaboration between all stakeholders and refugee leaders to advocate for the inclusion of refugee health issues in health related policies.

\section{Access to antiretroviral therapies (ARTs)}

Of the 12 relevant policy documents reviewed in this study, only three made provision for refugees' access to ARTs in South Africa. On the other hand, the South African constitutional court recommends that refugees should access free health care services including ART and be treated equally as their South African counterparts (Republic of South Africa 1998; Wachira 2008). Studies conducted among refugees in South Africa revealed that all the refugees interviewed reported that they were denied access to ART at public hospitals (Apalata et al. 2007; Crush \& Tawodzera 20l4; Manirangena 20l4; Nkosi 20l4; Vearay 2014; Zihindula 2015). The target of the National Strategic Plan for 2010 -2019 is to eliminate HIV/AIDS \& TB (DOH 20I5) but it does not provide for refugees' access to ART. This is a challenge because refugees are integrated in the communities and inter-marry with the local South African population. They are therefore likely to transmit the virus if infected and untreated (Zihindula et al. 20I5).

Wachira (2008:20) examined the provision of ART to refugees in the city of Johannesburg and his findings suggested that public hospitals and clinics failed to implement the $\mathrm{DoH}$ directive to provide ART to refugees. Instead they refer them to NGOs that provide health services. Another study conducted by Maniragena (20l4) among refugees and their service providers in the city of Cape Town found that refugees were unable to access ART on the basis that they did not have green bar-coded Identity Documents (ID). These findings suggest that policy provisions are not being carried out in practice. Moreover, existing research suggests that what is stipulated in the policy document regarding refugees' access to ART is not being observed in practice (SAMP 20I5; Vearey 20I5; Zihindula et al. 20I5). This might be due to bad interpretation of the content in the policy or failure to implement what has been agreed upon with the international organisations that assist and care for refugees. Another factor could be the lack of knowledge by implementers as well as the health care service providers. This calls for well-coordinated and monitored policy implementation processes at the health facility level that will include training of the $\mathrm{HCPs}$ on the relevant policy documents and raising awareness of refugee's rights to access ART.

\section{Access to mental health services}

Mental health problems amongst refugees continue to grow and remain a challenge for many countries that host forced migrants (Magqibelo et al 2016). Studies have shown that across the world, refugees are increasingly presenting with symptoms related to mental health problems (Bhuga et al 2015; SchoulerOcak 20I5) and refugees based in South Africa are not an exception. Their situation worsens when they fail to access healthcare services for mental health issues (Zihindula et al 2015) due to diverse barriers.

Existing literature suggest that there is an increase in the number of refugees experiencing challenges accessing mental health services in America and Europe (Duncan 2015; Langlois et al. 2016; Shannon et al. 20l I). The challenges include a lack of knowledge about available healthcare services and treatment options, language difficulties, shame and fear (Bhugra et al. 2015; Schouler-Ocak 2015; Weissbecker \& Leichner 2015). In addition to the above, provision for refugees to access mental health care even in years to come has not been taken into consideration (Zihindula et al. 20I5). Further research has revealed that South Africa faces major challenges in the provision of mental health services in public healthcare facilities (Mkhize \& Kometsi 2008). The situation is however worse for refugees because, as shown in this study, policies and strategic health plans have not adequately provided for them.

For example, the South African National Mental Health Policy Framework and Strategic Plan 20I32020 does not include any provision for refugee access to mental health care services (DOH 20|4). In this study, less than half of the policies reviewed provide for refugees access to mental healthcare services. Moreover, in South Africa, common mental disorders remain largely undetected and untreated at the PHC level (Peterson \& Lund 20II).

While studies have shown that South Africa's health policy ignore mental health issues, Petersen and Lund stated that instead of considering the illness narratives which are the subjective experiences of the distress of patients, the nurses focus solely on clinical examination of the body (Petersen \& Lund $20 \mathrm{II}$ ). It is also revealed that health care workers fail to account for somatic complaints where physiological causes are lacking (Mkhize \& Kometsi 2008; Petersen \& Lund 20II). The provision of mental health care in South Africa, like in many other countries in the developing world, remains therefore entrenched in a biomedical model, and tends to rely on psychiatric health care workers and trained primary health care (PHC) clinicians managing chronic patients at the basic care level (Grazin 2008; Marais \& Peterson, 2015). Such a model of mental health management excludes the common mental health disorders like depression, anxiety and other 
behavioural problems which refugees may suffer from. However, the question remains whether the adoption of a new model will make provision for refugee access to mental health care services in South Africa, given that even the citizens are facing some challenges in accessing mental health care.

\section{Provision of interpreters at public health facilities}

Despite many calls made from public health researchers about the need to use interpreters to assist refugees (Apalata et al. 2007; Gilson \& Mclntyre 2007; Vearey 20I4; Zihindula et al. 2015), none of the 12 policy documents make provision for translators at public health facilities to help refugees who cannot speak the South African local languages. This situation ultimately compromises the treatment of refugees since communication is the key and first step to accessing health care services. The implication of the lack of such a provision is that language barriers undermine the health care providers' ability to have proper understanding of the patients' problems and therefore makes it difficult to carry out diagnosis and treatment (Apalata et al. 2007; Zihindula 2015).

Researchers recommend that interpreters be made available at public health facilities to assist refugees (Crush \& Tawodzera 2014; Nkosi 2014; Veary 20I5; Zihindula et al. 2015). The use of interpreters in health care, however, comes with challenges, amongst which is the lack of trained and experienced interpreters (Hadziabdic et al. 20/5). Another concern is the inability of some health care professionals to work with an interpreter which may effect the client's health care services (Gilson and Mclntyre 2007). Nonetheless, interpretation in health facility comes with advantages (Foundation House 20/3). The Foundation House of Australia (20/3), identified the following advantages of using interpreters: improved quality of care, client safety, improved access to health care services, avoidance of unnecessary health care expenditure, reduced stress for family and the avoidance of the HCPs risks for litigation. However, we found no study on the role of interpreters in the delivery of health services in South Africa.

The population of South Africa reached 54948756 in June 2016, (United Nations 2016). Of this total, 6, 19 million were estimated to be living with HIV in 2015 (StatsSA 20I5). In addition, there are 65000 documented refugees in South Africa (StatsSA 2015; UNHCR 20I5). This number does not include asylum seekers and undocumented migrants. This number is high and the number of forced migrants coming to South Africa continues to grow, which negatively impact the health of the South Africans if refugee's access to healthcare services is 3243 not facilitated by policies in place. While policies that favour refugees' access to healthcare services remain poorly implemented, the few that provide for refugees' wellbeing have not been well documented and the implementation of those few that advocate for refugees' wellbeing has not been successful. These together undermine the achievement of the universal access to health care in South Africa.

\section{Limitations}

This study has some limitations. Firstly, the researchers were not able to collect more information due to the limited time within which the thesis had to be completed as well as the financial challenges of having to travel to policy-makers' offices for interviews. Although a comprehensive review of relevant documents was conducted, the documents may not have been exhaustive. We may have missed some documents which are relevant to refugees' access to health care services.

\section{Conclusion}

Health policy documents have not made adequate provision for refugees to access health care services in South Africa. Consequently, issues of refugees have not been addressed accordingly by relevant policies. The findings of this study calls for health policy makers' attention to the issue of refugee health despite the government's limited financial and human resource capacity, because refugee health has important health ramifications for the citizens and the country at large. Further, government and policy makers should facilitate access to resources that will strengthen health facility management, improve general awareness of national health policies among practitioners and refugees as well as enable the implementation thereof.

\section{References}

ACMS. 20I5. "Queue here for corruption: measuring irregularities in South Africa's asylum system: $A$ report by the Lawyers for Human Rights and the African Centre for Migration \& Society". South Africa: University of Witwatersrand

Akintola, O.O \& Akintola, O. 2015. "West Africans in the informal economy of South Africa: the case of low skilled Nigerian migrants". Rev Black Polit Econ, 42:379-398, DOI: $|0.1007 / \mathrm{s}| 2 \mid 14-015-$ 921I-8

Amnesty International. 2015. "Al Slams Government of South Africa for Failing to Stop Xenophobia". Accessed on 0l/05/2015 from: http://www.enca.com/south-africa/AmnestyInternational-slams-government-failing-stopxenophobia

http://aps.journals.ac.za 
Annan, N. 2014. "Violent Conflict and civil strife in West Africa: causes, challenges and prospects". International Journal of Security and Development, 3, (2), DOI, http://doi.org//0.5334/sta.da

Apalata, T., Kibiribiri, E. T., Knight, S., \& Lutge, E. 2007. 'Refugees' perceptions of their health status and quality of health care services in Durban, South Africa: A Community -Based Survey". Durban, South Africa: Health Systems Trust.

Asgary, R \& Segar, N. 20I I. "Barriers to health care services among refugee asylum seekers". Journal of Health Care Poor Underserved, 22, (2): 506522

Aspinall, P \& Watters, C. 20I0. "Refugees and Asylum Seekers: A review from an equality and human rights perspective". Equality and Human Rights Commission Research Report Series, University of Kent. Accessed on 22/12/2015 from: http://www.equalityhumanrights.com/uploaded fil es/research/refugees_and_asylum_seeke rs_research_report.pdf

Bachishoga, B.K \& Johnson, A. K. 2013. "Impact of mobile phones on integration: the case of refugees in South Africa". The Journal of Community Informatics, 9, (4)

Bhugra, D., Gupta, S., Schouler-Ocak, M., GraeffCalliess, I., Deakin, N.A., Qureshi, A., et al. 2014. "EPA guidance mental health care of migrants". European psychiatry: the journal of the association of European Psychiatrists, 29, (2):107-II5 PubMed PMID: 24503244

Bonatar, S. 2013. "The challenges of health disparities in South Africa". The South African Medical Journal, Vol I03(I)

Burns, K.J. 20I0. "Mental health services founding and development in KwaZulu-Natal: a tale of inequity and neglect". SAMJ, 100, (10)

CMS. 2012. "Comments on the National Health Insurance Policy Paper of 12 August 201 I". South Africa: Council for Medical Schemes

CoRMSA. 2011. "Protecting Refugees, Asylum Seekers and Immigrants in South Africa during 2010". CoRMSA Johannesburg. Accessed on: 20/03/20I5 from: http://www.cormsa.org.za/wpcontent/uploads/2008/06/CoRMSA-Report2011.pdf

Crush, J., \& Tawodzera, G. 20/4. "Medical xenophobia and Zimbabwean migrant access to public health services in South Africa", Journal of Ethnic and Migration Studies, 40, (4), 655-670

DHET. 2014. "List of occupations in high demand 2014: Government Gazette". Republic of South Africa: Higher Education and Training
DOH. 2014. "Department of Health-Annual Report 2012-20/3". Republic of South Africa: National Department of Health

Dudley, L., Selebano, T.E., Nathan, R, et al., 2013. "Re-launch of the South African Society of Medical Managers (previously known as the Medical Administrators Group)". South African Medical Journal, 103, (I):23

Duncan, F.G. 20I5. "Refugees' healthcare: Towards healing relationships". Canadian Social Science, II, (9)

Foundation House. 2013. "Promoting the engagement of interpreters in Victorian health services". Australia: the Victorian Foundation for Survivors of Torture

Gilson, L \& Mclntyre, D. 2007. "Post-apartheid challenges: household access and use of care". International Journal of Health Services, 37, (4):673-69।

Goddard, M, \& Smith, P. 200I. "Equity of access to health care services: Theory and evidence from the UK". Soc Sci Med, 53: I I 49- I I 62

Gray, A \& Vawda, Y. 2014. "Health Policy and Legislation: The South African Health Review 2013/I4". Health Systems Trust

Grazin N. 2008. "Towards an integrated mental health service: a situation analysis of the Lower Orange District". Durban: Health Systems Trust. Accessed on 27/Nov/2015 from: URL: http://www.hst.org.za/uploads/files/integ_mental.p df

Greenburg, J \& Polzer, T. 2008. "Neighbors in Need: Zimbabweans seeking Refuge in South Africa". Human Right Watch

Griffiths, M. 20I5. "Here, Man Is Nothing: Gender and Policy in Asylum Context". Men and Masculinities, 18, (4): 468-488

Haddad, S., Mohindra, K. 2002. "Access, opportunities and communities: ingredients for health equity in the South". Paper presented at the public health and international justice workshop. New York: Camegie Council on Ethics and International Affairs

Hadziabdic, E., Lundin, C., Hjelm, K. 2015. "Boundaries and conditions of interpretation in multilingual and multicultural elderly healthcare", BMC, Health Services, Vol I5:458

Harris, B., Goudge, J., Ataguba, E.J., Mclntyre, D., Nxumalo, N., Jikwana, S \& Chersich, M. 201 I. "Inequities in access to health care in South Africa". Journal of Public Health Policy, Vol 32 (I): sl02-s 123

HRW. 2009. "South Africa: Improve Migrants' Access to Healthcare Xenophobic Violence, Discrimination Imperil Immigrant Health". Human Right Watch 
HRW. 20I5. "Refugees in South Africa". Accessed on the I I/July/20I5 from: http://www.hrw.org/world-report/2015/countrychapters/south-africa

HRW. 2015. "South Africa". Accessed on 12/01/2015 from: http://www.hrw.org/worldreport/2015/country-chapters/south-africa

IOM. 1993. "International Migration Bulletin No, 3". Geneva: United Nations

Langlois, V.E., Haines, A., Thomson, G \& Ghaffar, A. 2016. "Refugees: towards better access to healthcare services". The Lancet, 387, ( 00 |6):319-32 I

Levesque, J.F., Harris, M.F., \& Russell, G. 2013. "Patient centered access to health care: conceptualizing access at the interface of health systems and populations". International Journal of Equity in Health, 12:18, accessed from: http://www.equityhealthi.com/content/I2/I//8

Magqibelo, L., Londt, M., September., S \& Roman, N. 2016, "challenges faced by unaccompanied minorrefugees in South Africa", Social Work/Maatskalike Werk, Vol 52 (I):5

Maniragena, J.E. 20l4. "An evaluation of service effectiveness of selected refugee service providers in urban and surrounding areas of the Cape Town Metropolitan area", Unpublished Masters' thesis submitted at Cape Peninsula University of Technology in South Africa

Marais, L.D. \& Petersen, I. 2015. "Health system governance to support integrated mental health care in South Africa: challenges and opportunities". International Journals of Mental Health Systems, 9, (I4)

Mash, R., Malan, Z., von Pressentin, Z \& Blitz, J. 2015. "Strengthening primary health care through primary care doctors: the design of a new national Postgraduate Diploma in Family Medicine", South African Family Practice, I (I):I-5

Matsoso, M, Fryatt, R \& Andrews, G. 2015. "The South African health reforms 2009-2014: moving towards universal coverage". Pretoria: Juta and Company

Matsoso, M.P. 2013. "National Health Insurance: the first 18 months". South African Medical Journal, I03, (3): I56-I58. DOI: I0.7I96/SAMJ.660।

McKeary, M \& Newbold, K.B. 2010. "Barriers to care: The challenges for Canadian refugees and their health care providers". Journal of Refugee Studies, 23, (4), 523-545

Milosevic, D. 2012. "The NSW Refugee Health Service: Improving refugee access to primary care". Australian Family Physician professional Vol. 4I, No. 3, March 2012

Mkhize, N \& Kometsi M.J. 2008. "Community Access to Mental Health Services: Lessons and Recommendations. In 2008 South African Health
Review Edited by Barren, P. (Ed): Health Systems Trust pp. 103-II3.

Moyo, N. \& Müller, J.C. 20II. 'The influence of cultural practices on the HIV and AIDS pandemic in Zambia" HTS Teologiese Studies/Theological $\begin{array}{llll}\text { Studies } & 67(3), & \text { Art. } & \text { No770:5 }\end{array}$ doi. 10.4102/hts.v67i3.770

Naidoo, S. 2012. "The South African national health insurance: a revolution in health-care delivery". Journal of Public Health, 34, (I): I 49- I50

NDOH. 2014. "National Strategic Plan 2014/2015 2018/2019". South Africa: National Department of Health

Nevondwe, L \& Odeku, O.K. 2013. "The rights of Access to Health Care Services: Pitfalls and Prospects". Mediterranean Journal of Social Sciences, Vol 4 (13)

Nkosi, G.N. 2014. "Influences of xenophobia on accessing health care for refugees and asylum seekers in Johannesburg". Unpublished Master's Thesis submitted at University of Witwatersrand, Johannesburg: South Africa

Olivier, A., \& Mossialos, E. 2004. "Equity of access to health care: outlining the foundations for action". Journal of Epidemiol Community Health, 58:655658

Petersen I. 2004. "Primary level psychological services in South Africa: can a new psychological profession fill the gap"? Health Policy Plan, 19(I):32-40.

Petersen, I \& Swartz, L. 2002. "Primary Health Care in the era of HIV/AIDS: some implications for health systems reform". Soc Sci Med, 55, (6): $1005-1013$

Peterson, I \& Lund, C. 20I I. Mental health services delivery in South Africa from 2000-2010: one step forward, one step back. South African Medical Journal, I0I, (I0):75I-757

Pillay, Y and Thulare, A. 20II. "Making Healthcare Equitable". South Africa: The Mail and Guardian

Republic of South Africa. 1998. "South African Refugees Act No 130, 1998”. Vol. 402 No 19544, December 2, 1998. Cape Town: Office of the President

SAMP. 20I5. "Xenophobic violence in South Africa: denialism, minimalism, realism". Migration Policy Series, No 66

Schouler-Ocak, M. 20I5. "Mental health care for immigrants in Germany". Nervenarzt: Epub ahead of Print

Shannon, P., Im, H., Becher, E., Simmelink, J., Weiling, E., O'fallion, A. 20II. "Screening for trauma, torture, and mental health symptoms among newly arrived refugees: A national survey of US refugee health coordinators". Journal of Immigrants \& Refugee Studies, 19:380-394 
Shannon, P., Im, H., Becher, E., Simmelink, J., Weiling, E., O'fallion, A. 20II. "Screening for trauma, torture, and mental health symptoms among newly arrived refugees: A national survey of US refugee health coordinators". Journal of Immigrants \& Refugee Studies, 19:380-394

Silove, D., Steel, Z., Bauman, A., Chey, T., \& McFarlane, A. 2007. "Trauma, PTSD and the longer-term mental health burden amongst Vietnamese refugees: A comparison with the Australian-born population”. Soc Psychiatry Psychiatr Epidemiol, 42: 467-476.

Sirin, R.S \& Rogers-Sirin, L. 2015. "The educational and mental health needs of Syrians refugee children". Washington DC: Migration Policy Institute

South African Academy of Family Physicians. 2014. "The contribution of family physicians to district health services: a position paper for the National Department of Health". Accessed on 09 $/ 09 / 2015$ from: http://www.saafp.org/index.php/news/48national-position-paper-on-family-medicine

Spiegel, B.P \& Nankoe, A. 2004. "UNHCR, HIV/AIDS and refugees: Lessons Learned". Forced Migration Review, 19, 21-23

StatsSA (20I5). "Midyear population estimates 2015". Statistics South Africa: Statistical release PO302

Szajina, A \& Ward, J. 2015. "Access to health care by refugees: a dimensional analysis. Nursing Forum" 50, (2):83-89. Doi:I0.III/nuf.|205I. Epub20|4 Jan 3

UNHCR. 20II. "Ensuring Access to Health Care: Operational Guidance on Refugee Protection and solutions in urban areas". The UN Refugees agency

UNHCR. 2012. "Operational guidance mental health \& psychosocial support programming for refugee operations". UNHCR, the UN Refugee Agency. Accessed on $8^{\text {th }} / 09 / 2015$ from: http://www.unhcr.org/525f944779.pdf

UNHCR. 20I2. "Operational guidance mental health \& psychosocial support programming for refugee operations". UNHCR, the UN Refugee Agency. Accessed on $8^{\text {th }} / 09 / 2015$ from: http://www.unher.org/525f94479.pdf
UNHCR. 2015. "Syria regional refugee response: inter-agency information portal". Government of Turkey: UNHCR

UNHCR. 20I5. "UNHCR country operations profileSouth Africa: The UN Refugee Agency". Accessed on $20^{\text {th }} / 08 / 2015$ from:

http://www.unhcr.org/pages/49e485aa6.html

Vearey, J. 2014. "Healthy migration: A public health and development imperative for South (ern) Africa". South African Medical Journal, Vol 104 (I0): 663-664

Wachira, G.M. 2008. "Migrants' rights to health in Southern Africa". Forced Migration Studies Programme, Johannesburg: University of Witwatersrand

Warfa, N., Curtis, S., Watters, C., Carswell, K., Ingleby, D \& Bhui, K. 20I2. "Migration experiences, employment status and psychological distress among Somali immigrants: a mixedmethod international study". BMC Public Health, 12:749

Waters, H.R. 2000. "Measuring equity in access to health care". Social science \& Medicine, 5I: 599612

Weissbecker, I \& Leichner, A. 2015. "Addressing mental health needs among Syrian refugees: providing non-partisan, expert information and analysis on the Middle East". Middle East Institute

Zihindula, G. 2015. "Perceptions of medical doctors on refugees' health seeking behaviours in Durban, South Africa", European Scientific Journal, II, (26): |857-788|

Zihindula, G., Meyer-Weitz, A, \& Akintola, O. 2015. "Lived experiences of Democratic Republic of Congo Refugees facing Medical Xenophobia in Durban, South Africa", Journal of Asian and African Studies, DOI: 10.1177/0021909615595990

Zihindula, G., Meyer-Weitz, A., Akintola, O. 2015. "Access to health care services by refugees in Southern Africa: A critical review of literature", Southern Africa Journal of Demography, 16 (I), June 2015 